\title{
継続歩行距離と休䟤施設の密度基準 \\ 東京駅および大手町駅周辺地区を対象に \\ CONTINUOUS WALKING DISTANCE AND CRITERIA FOR DENSITY OF RESTING PLACES
}

Application to Tokyo central station and Otemachi station

\author{
薄井宏行*1, 樋野公宏*2 \\ Hiroyuki USUI and Kimihiro HINO
}

\begin{abstract}
Continuous walking distance distribution and density of resting places (e.g., benches) was investigated by applying the nearest neighbour distance distribution. The surroundings of Tokyo central station and Otemachi station were selected as the empirical study area. It was found that (1) the probability that the nearest distance between resting places is longer than $100 \mathrm{~m}$ is 0.28 ; (2) if flower beds are used as resting places, then its probability is 0.14 ; and (3) if its probability is close to 0 , the number of additional resting places is increased to 194 which is approximately 3 times greater than the present number.
\end{abstract}

Keywords : Continuous walking distance, Resting place, Density, Nearest neighbor distance, Distance distribution 継続歩行距離, 休㮩施設, 密度, 最近隣距離, 距離分布

\section{1. はじめに}

いま，日本は世界で有数の高齢社会の国である，将来に向けて， 人口に占める高齢者の割合はさらに増加する見込みである. 高齢化 が進行すると, 自家用車等による移動が困難となる交通弱者も増加 する. とくに, 地方部や都心郊外の場合, 日常の交通手段に占める 自家用車の分担率は高い。このため, 歩いて暮らせるまちづくりに 向けた様々な取り組みがなされている。高齢社会における交通弱者 の問題は, 地方部や都心郊外に固有の問題ではなく, 都心において も顕在化しつつある問題である. 東京などの都心の場合, 主な交通 手段は鉄道等の公共交通機関と徒歩である. とくに, 東京駅や大手 町駅のように, 大規模な交通結節点の場合, 徒歩による移動が主で あり，歩行距離は数百メートルとなる場合もある．高齢者が難なく 継続歩行できるほど, ベンチ等の休㮩施設（以降,「休頽施設」と記 寸.）は十分に整備されていない. 国土交通省都市局が2014年8月に 発出した技術的助言「健康・医療・福祉のまちづくりの推進ガイド ライン」によると, 歩行の継続距離は概ね500mから 700mであり, 後期高齢者になると減少する傾向にある11. また, 居住地から $400 \mathrm{~m}$ 以内においてベンチ等の総数が多いほど，高齢者の歩行を促す傾向 にある2). 継続歩行距離を短くする方法として，1)休㓤施設の数を増 加させること,2)休貌施設の配置を工夫することなどが挙げられる.
ところが，継続歩行距離と休覣施設の数や配置の基準については定 められておらず，両者の関係については，既往研究においても十分 に検討されていない。

本稿に関連する主な既往研究として，1)歩行空間における高齢者 のためのベンチの設置間隔を提案したもの，2)高齢者の継続歩行距 離やベンチ等の利用実態を明らかにした研究がある。1)に関連する 既往研究として，土居ほか(1999) と北川ほか(2000)は，高齢者の移 動を支援する施策の一つとして，歩行空間におけるベンチ等の休息 施設を整備する必要性を指摘している。兵庫県明石市において休憩 施設の設置間隔の希望調查を実施した結果，1)高齢者の約65\%が

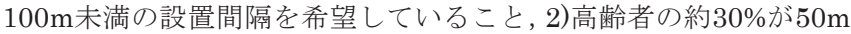
未満の設置間隔を希望していることを明らかにしている。これらの 調查結果に基づき, ベンチの設置間隔として $50 \mathrm{~m}$ から $100 \mathrm{~m}$ 程度の 間隔を提案している33) 4). 休稔施設の設置間隔の希望は, 高齢者の継 続歩行距離を反映するものである。また，2)に関連する既往研究と して，大島ほか(2003)は，東京都品川区において高齢者を対象に心゙ ンチ等の「座りスペース」の利用の実態を調査した結果，歩行に何 らかの不自由がある人の約 $80 \%$ は駅における「座りスペース」を重 視していることを明らかにしている5)。柿沼ほか(2008)は，座ってい るか立っているかを問わず，移動を止め，休憩や会話・飲食等の行

\footnotetext{
*1 東京大学大学院工学系研究科都市工学専攻 助教 - 博士 (工学)

*2 東京大学大学院工学系研究科都市工学専攻 准教授 ·博士 (工学)
}

Assist. Prof., Dept. of Urban Engineering, School of Engineering, The University of Tokyo, Dr.Eng.

Assoc. Prof., Dept. of Urban Engineering, School of Engineering, The University of Tokyo, Dr.Eng. 
為を行っているものを「滞留」と定義している. 東京都豊島区の商 店街を対象とした調查の結果，1)高齢者の滞留場所として花壇等の 段差はベンチと同様の効果があること, 2) 高齢者の滞留間の平均距 離は約 $550 \mathrm{~m}$ であることを明らかにし，長時間の回遊を可能にする ためには, 滞留可能な場所を一定の間隔で設けることが有効である ことを指摘している ${ }^{6}$. ところが，休㮩施設の数や配置の基準につ いては今後の検討課題とされている. 現実の都市空間の場合, ベン チ等の休想施設は大小様々な間隔で配置されることから, 確率論的 な考察をする必要があると考えられる.

本稿では, ある区域において, 休噭施設の量（密度）と継続歩行 距離の関係を, 平面上における任意の点から最近隣の点までの距離 分布 (以降, 「最近隣距離分布」と記す.) を規範として考察する. 休数施設を点としてモデル化することにより, ある休㮩施設から最 寄りの休賃施設までの継続歩行距離を最近隣距離分布へ州着させる ことができる. 最近隣距離分布に着目寸ることで，1)休鄎施設の密 度に応じた継続歩行距離分布の評価，2)継続歩行距離分布を改善す るために更に必要な休㮩施設の総数を明らかにすることができる.

以降，第2節において，休憩施設の規範的な配置パターンを想定 し, 平面上における最近隣距離分布を定式化する. 第3節において, 休蘩施設の密度の変化に対する継続歩行距離分布の変化の感度分析 を行うことにより，休息施設を増加させることによる継続歩行距離 の減少具合を定量的に評価する. 第4節において, 東京駅および大 手町駅周辺地区を対象に, 現状の休慜施設の密度から継続歩行距離 分布を推定する. 第5節において, 継続歩行距離を減少するために 必要な休憩施設の整備量を明らかにし, 整備方針を提案する. 第6 節において, まとめと今後の課題を述べる。

\section{2. 休鄎施設の規範的配置パターンに基づく最近隣距離分布}

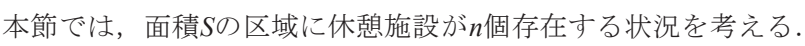
平面上において, 任意の休鄎施設 $i$ を点 $\mathrm{F}_{i}$ として表す. Fig.1左のよう に, 任意の点 $\mathrm{F}_{i}$ から最寄りの休想施設までの最近隣距離 $R$ が $r$ 以下と なる確率 $F(R \leq r)$ は, 点 $\mathrm{F}_{i}$ を中心と寸る半径 $r$ の内において, 休䈍施 設が少なくとも 1 個存在する確率に等しい. 半径 $r$ の内内休礊施設 が $k$ 個存在する確率を $\operatorname{Pr}\{r, k\}$ と記すとき, $F(R \leq r)$ は次式のようにな る :

$$
F(R \leq r)=1-\operatorname{Pr}\{r, 0\} .
$$

ここで，休㕷施設の規範的な配置パターンとして，一様ランダムな パターンを仮定する. このとき, $\operatorname{Pr}\{r, k\}$ は次式のように二項分布と して記述される：

$$
\operatorname{Pr}\{r, k\}=\frac{n !}{k !(n-k) !}\left(\frac{\pi r^{2}}{S}\right)^{k}\left(1-\frac{\pi r^{2}}{S}\right)^{n-k} .
$$

$n / S=\rho$ は定のもとで， $n$ を十分に大きくすると，

$$
\operatorname{Pr}\{r, k\}=\frac{\left(\rho \pi r^{2}\right)^{k}}{k !} e^{-\rho \pi r^{2}} .
$$

(1)式と(3)式から, 休息施設が十分に多くかつ一様ランダムに配置さ れているとき， $F(R \leq r)$ は次式のようになる：

$$
F(R \leq r)=1-e^{-\rho \pi r^{2}} .
$$

$F(R \leq r)$ は最近隣距離 $R$ の累積分布関数であることに注意すると, $R$
の確率密度関数 $f(r)$ と次式の関係にある：

$$
F(R \leq r)=\int_{0}^{r} f(R) d r=1-e^{-\rho \pi r^{2}} .
$$

従って，(5)式の辺々を $r て ゙$ 微分することにより，1)区域の面積 $S$ は休 憩施設の面積と比較して十分に大きく，2)休櫋施設が十分に多くか つ一様ランダムに配置されている場合, 任意の休賃施設から最寄り の休覣施設までの最近隣距離分布は：

$$
f(r)=2 \rho \pi r e^{-\rho \pi r^{2}} .
$$

(3)式の近似式に基づいて以降の議論を展開する際に，1)nは十分 に大きく，2)休数施設は一様ランダムに分布すると仮定する妥当性 を検討する. Getis and Boots(1978)が指摘するように， $n>20$ かつ $\pi r^{2} / S<0.05$ のとき，(3)式は(2)式の良い近似を与える7). 腰塚(1985) は，点の数 $n$ が 10 から 30 程度の場合について，無限平面における最 近隣距離分布（(6)式）と現実の都市のように有限平面における最近 隣距離分布を比較した結果，前者は後者とよく適合することを実証 している8). 後述するように, 東京駅および大手町駅周辺地区（後 述の「対象地区」）において，1)ベンチの設置地点の総数は67，2） 着座可能な花壇等を含めた休蒩施設の総数は 97 である.ゆえに, (3) 式は(2)式の良い近似を与える程度に，nは十分に大きいといえる.

また，車道上や駅構内およびオフィスビル等の一部は歩行空間と して不適切な空間であるため, 一様ランダム性の仮定は強い仮定で ある。このため, Clark and Evans(1954)の方法を用いて，この仮 定の妥当性を統計的に検定する。いま，任意の休慜施設 $\mathrm{F}_{i}$ 加最寄

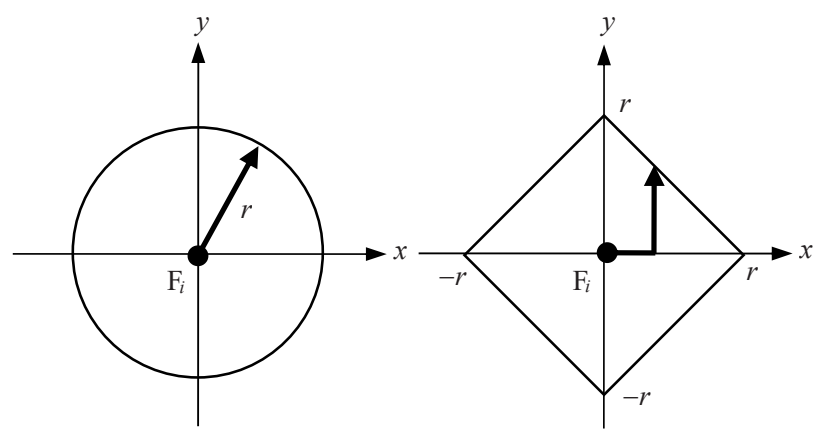

Fig.1 Euclidean distance and Manhattan distance

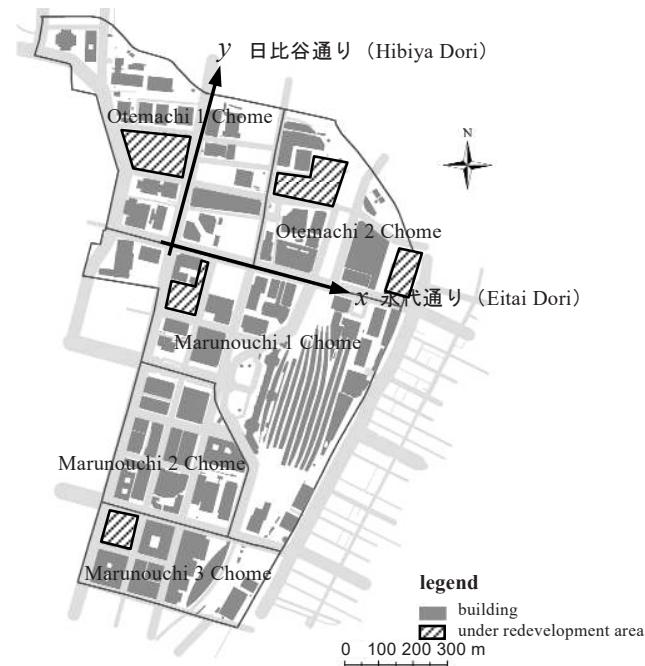

Fig.2 Location of buildings in Otemachi and Marunouchi 
りの休㮩施設までの最近隣距離の平均を $r_{0}$ と記すとき, 一様ランダ ム性の検定統計量 $Z$ は次式のようになる ${ }^{9)}$ :

$$
z=\left(r_{O}-\frac{1}{2 \sqrt{\rho}}\right) / \sqrt{\frac{4-\pi}{4 \pi n \rho}} \sim N(0,1) .
$$

Fig.2において, 斜線部は2018年1月時点において再開発事業に伴 う建設工事中の区域を表す注1)。このため， $\rho$ を算出する際に，対象 地区の面積 $S\left(1,090,875 \mathrm{~m}^{2}\right)$ から斜線部の面積 $\left(71,937 \mathrm{~m}^{2}\right)$ を除く と, 1)ベンチのみの場合, $z$ の值は-2.53，2)着座可能な花壇等を含 めた休憩施設の場合, $z$ の值は-1.52 となる. 有意水準 $5 \%$ の下で, ベ ンチ設置地点の分布は一様ランダムであるとの仮定は棄却される一 方で, 花壇等を含めた休㮩施設の分布は一様ランダムであるとの仮 説は棄却されないことがわかる. 近年, 対象地区では, 賑わい創出 のために, 道路空間やオフィスビルの1階部分は面的な歩行空間と して整備されつつある. 従って, 休㮩施設が一様ランダムかつ十分 に多く配置されていると仮定することは妥当であると考えられる.

ところで, Fig.2のように, 東京駅や大手町駅周辺地区の場合, 道 路網のパターンは概ね格子状である. 加えて, 建物の1階部分と東 京駅の改札内はほぼ格子状の通路網および広場で構成され, 歩行空 間として使用されている. 確かに, 歩道等のネットワーク空間上に おける休頽施設の配置モデルも考えられる. ところが, 現実の都市 空間における歩行経路の自由度は, 平面上よりも低い場合もあれば. 幅員の広い通路や広場のようにネットワーク空間上よりも高い場合 もある，上述のように，対象地区では，道路空間やオフィスビルの 1階部分は面的な歩行空間として整備されつつある. このため, 理 論展開が容易である稠密な格子状通路網モデルを考える10). Fig.2の ように, 永代通りと日比谷通りに沿って $x$ - $y$ 平面座標系を設定し, 平 面上の稠密な格子状通路網上において, ある休稳施設から最寄りの 休款施設までの直交距離に基づく最近隣距離分布を考えてみよう.

Fig.1右のように, 任意の休馝施設 $\mathrm{F}_{i}$ から最寄りの休息施設までの直 交距離に基づく最近隣距離 $R$ が $r$ 以下となる確率 $F_{\operatorname{man}}(R \leq r)$ は, 点 $\mathrm{F}_{i}$ を中心とする辺長 $\sqrt{2} r$ の菱形内において, 休息施設が少なくとも 1 個存在する確率に等しい。この確率は，(3)式において円の面積 $\pi r^{2}$ を菱形の面積 $2 r^{2}$ に置き換えたものに相当する ${ }^{11)}$ :

$$
F_{\operatorname{man}}(R \leq r)=1-e^{-2 \rho r^{2}} .
$$

(8)式の両辺をrで微分することにより，任意の休櫋施設から最寄り の休憩施設までの直交距離に基づく最近隣距離分布は：

$$
f_{\operatorname{man}}(r)=4 \rho r e^{-2 \rho r^{2}} .
$$

\section{3. 休憩施設の増加と継続歩行距離の減少の定量的評価}

Fig.3は休㮩施設の密度 $\rho$ を変化させたときの直交距離に基づく最 近隣距離分布の変化を描いたものである. Fig.3において,

$$
r_{\text {grid }} \equiv 1 / \sqrt{\rho}=\sqrt{S / n}
$$

は休憩施設の規範的な配置パターンとして, 正方格子状を想定した 場合の最近隣距離であり, 一定の值をとる．たとえば，休䕀施設の 設置間隔の基準として $r_{\text {grid }}$ を考える. このとき， $f_{\text {man }}(r)$ の最頻值は， $r_{\text {grid }} / 2 \sqrt{2} \cong 0.35 r_{\text {grid }}$ となる. Fig.3から，一様ランダムな配置パター

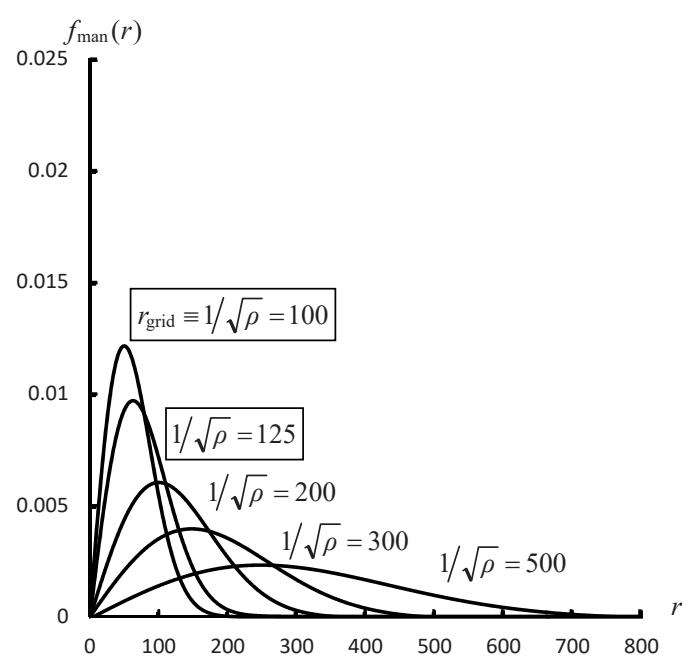

Fig.3 The nearest neighbor distance distribution based on Manhattan distance

Table1 Comparison of the probability that the nearest neighbour distance to resting place is more than 100 metres (based on Manhattan distance)

\begin{tabular}{c|c}
\hline$r_{\text {grid }}$ & $\alpha$ \\
\hline 50 & 0.00 \\
\hline 75 & 0.03 \\
\hline 100 & 0.14 \\
\hline 125 & 0.28 \\
\hline 200 & 0.61 \\
\hline 300 & 0.80 \\
\hline 500 & 0.92 \\
\hline
\end{tabular}

ンを想定すると， $r_{\mathrm{grid}}$ の值が大きいほど，1)直交距離に基づく最近隣 距離分布の平均, 標準偏差, 最頻值はそれぞれ増加すること, 2)最 近隣距離が $100 \mathrm{~m}$ 以上となる確率も増加する様子がわかる.

Table1は, 直交距離に基づく場合について, $r_{\text {grid }}$ の值の変化と最 近隣距離が $100 \mathrm{~m}$ 以上となる確率の変化の関係を示したものである。 Table1から，1)休款施設を $100 \mathrm{~m}$ 間隔で格子状に配置する基準のも とで, 直交距離に基づく最近隣距離が $100 \mathrm{~m}$ 以上となる確率は 0.14 であること，2)休覕施設を $200 \mathrm{~m}$ 間隔で格子状に配置する基準のもと で, 直交距離に基づく最近隣距離が $100 \mathrm{~m}$ 以上となる確率は 0.61 であ ることがわかる.

前述したように，既往研究における希望調查の結果から，1)高齢 者の約 $65 \%$ が $100 \mathrm{~m}$ 未満の設置間隔を希望し，2)高齢者の約 $30 \%$ が $50 \mathrm{~m}$ 未満の設置間隔を希望している，ところが，現実の都市空間に おいて，休憩施設を等間隔に設置するのは様々な理由により困難で あると思われる。そこで, 設置間隔 $r_{\text {grid }}$ が $100 \mathrm{~m}$ となる休㮩施設密度 のもとで，休憩施設を一様ランダムに配置すると， 0.14の確率で最 寄りの休喤施設までの直交距離に基づく最近隣距離は $100 \mathrm{~m}$ 以上と なることがわかった.このように, 休款施設の設置間隔 $r_{\text {grid }}$ のみでは, 現状の休馝施設の密度で実現しうる継続歩行距離分布を評価するこ とはできない. 本稿のように, 規範的な最近隣距離分布に着目寸る 
ことで, 継続歩行距離分布を確率論的に評価することができる.

継続歩行距離の最大許容值 $r_{\max }$ を設定し， $r_{\max } \leq r$ となる確率が $\alpha$ 以 下となる休毠施設の密度を検討する. 上述の場合, $r_{\text {max }}=100 \mathrm{~m}$ であ る.たとえば, $\alpha=0.61$ から $\alpha=0.14$ 一改善する場合を考える. Table 1 から, それぞれ $r_{\text {grid }}=200$ と $r_{\text {grid }}=100$ に対応する.（10)式を休䈍施設 密度 $\rho$ にいて解くと：

$$
\rho\left(r_{\text {grid }}\right)=\frac{1}{r_{\text {grid }}^{2}} .
$$

(11)式から, $\alpha=0.61$ か $\alpha=0.14$ へ改善するために必要な休息施設の 密度の増分は：

$$
\rho(100)=4 \rho(200) .
$$

つまり，休覣施設の密度を従前の 4 倍にする必要がある。

一般化すると，次式のようになる：

$$
F_{\operatorname{man}}\left(R \geq r_{\max }\right)=1-F_{\operatorname{man}}\left(R \leq r_{\max }\right)=e^{-2 \rho r_{\max }^{2}} \leq \alpha .
$$

(13)式より， $r_{\max } \leq r$ となる確率が $\alpha$ 以下となる休㮩施設の密度は：

$$
\rho \geq-\frac{\ln \alpha}{2 r_{\max }^{2}} \text {. }
$$

ただし， $0<\alpha<1$ より, $\ln \alpha^{-1}=-\ln \alpha>0$ が成立する. (14)式の右辺 は, $r_{\max } \leq r$ となる確率が $\alpha$ 以下となる休媳施設の密度の最低基準を確 率論的に導出したものである.（10)式と(14)式より, 正方格子状を 想定した場合の休㮩施設の設置間隔の基準を確率論的に定式化する ことができる：

$$
r_{\text {grid }}=\sqrt{\frac{2}{\ln \alpha^{-1}}} r_{\max } \text {. }
$$

$r_{\max }$ とаは政策的に設定される，たとえば，現状において最大継続 歩行距離 $r_{\max }$ を $200 \mathrm{~m}$ と設定している場合, 将来の最大継続歩行距離 $r_{\max }$ を $100 \mathrm{~m}$ 一改善することを考える.このとき, $r_{\max }$ よりも長くなる 継続歩行距離の確率 $\alpha$ を政策目標として設定することで, (14)式から 政策目標を達成するために必要な休䡯施設の密度を見積もることが できる.

Fig.4は，(15)式を用いて， $r_{\text {grid }}$ のグラフを $\alpha$ 関数として描いたも のである. Fig.4から，1） $r_{\text {grid }}$ は $\alpha^{*}=e^{-3 / 2} \approx 0.22$ を変曲点にもつ単調 増加関数であること，2) $r_{\max }$ が小さいほど， $\alpha^{*}<\alpha$ においてグラフの 凸性は強くなることがわかる，たとえば，現状において休熄施設の 設置間隔 $r_{\text {grid }}$ を $100 \mathrm{~m}$ に設定している場合を考える。このとき， $r_{\text {max }}$ を $100 \mathrm{~m}$ と設定すると， $\alpha=0.14$ となる. 政策目標として $\alpha=0.10$ と設 定するならば， $r_{\text {grid }}$ を $93 \mathrm{~m}$ 以下に設定する必要がある。このように， (14)式とFig.4から， $r_{\max }$ と蚛設定するときの密度と設置間隔がわか る.

\section{4. 現状の休鄎施設の密度に基づく継続歩行距離分布の推定}

東京駅および大手町駅周辺を対象に, 現状の休䕀施設の密度から 継続歩行距離分布を推定し, 休䕀施設の必要量を明らかにする. 以 降, 千代田区大手町 $1 丁$ 目, 大手町 $2 丁$ 目, 丸の内 $1 丁$ 目, 丸の内 $2 丁$ 目および丸の内 $3 丁$ 目を「対象地区」と記す. 地区面積は $1,090,875 \mathrm{~m}^{2}$ である。

Fig.5は, 対象地区の道路網, 街区, ベンチおよび着座可能な花壇

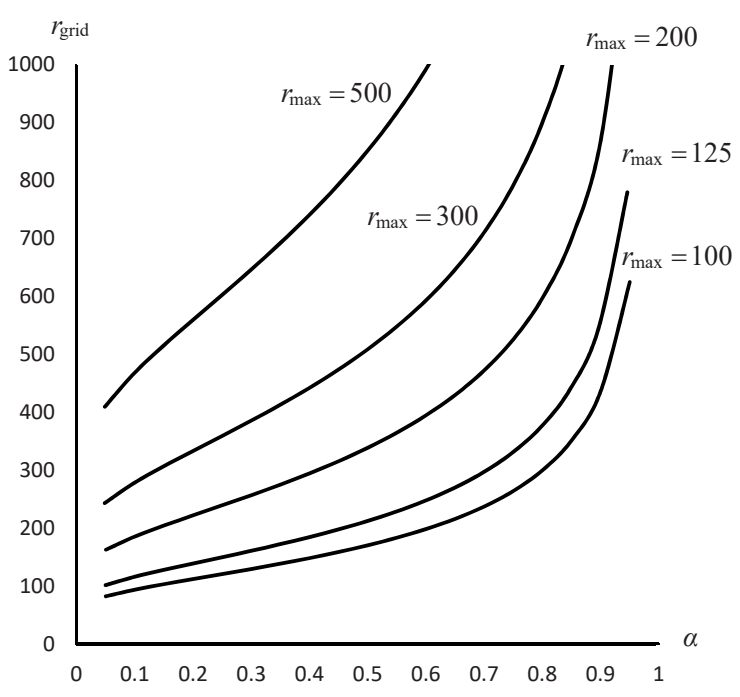

Fig.4 Interval of resting places based on stochastic approach

等の分布を描いたものである注2)，ただし，道路網の歩道，通路およ び公開空地に存在するベンチと花壇等に加えて, オフィスビルの 1 階部分の歩行可能な空間と丸の内 $1 丁$ 目の過半を占める東京駅の改 札内（以降，「公共空間」と記す.）に存在するベンチと花壇等を調 查対象とした. このとき, ベンチと花壇等の設置地点の総数はそれ ぞれ81（地上と地下におけるベンチの設置地点の総数はそれぞれ 67 と14）と 30 である. Fig.5から，1)東京駅八重洲口の休息施設は丸の 内側と比較して少ないこと，2)地下の公共空間における休稳施設の 総数は地上と比較して非常に少ないことがわかる.

前述したように，対象地区における道路網や通路網は概祮格子状 パターンである. Fig. 2 のよう, 永代通りと日比谷通りに沿って $x$ - $y$ 平面座標系を設定し, 直交距離に基づいて現状の休憩施設の密度で 実現しうる継続歩行距離分布を推定する。(10)式より，ベンチの設 置間隔 $r_{\text {grid }}$ は $128 \mathrm{~m}$ ，花壇等も含めた休䕀施設の設置間隔 $r_{\text {grid }}$ は $106 \mathrm{~m}$ である（ただし，Fig.2の斜線部の面積を除く場合， ベンチの設置間 隔 $r_{\text {grid }}$ は $123 \mathrm{~m}$, 花壇等も含めた休馝施設の設置間隔 $r_{\text {grid }}$ は $\left.102 \mathrm{~m}\right)$. 以 降, $r_{\text {grid }}$ の変化と継続歩行距離分布の関係を考察しやすくするために, $r_{\text {grid }}$ の值の概数をとる.このとき, Fig.3において，1)ベンチのみに 着目すると，概ね $r_{\text {grid }}=125$ となる休熄施設密度のもとで実現する継 続歩行距離分布であること，2)花壇等も含めた休櫋施設に着目寸る と, 概祆 $r_{\text {grid }}=100$ となる休鄎施設密度のもとで実現する継続歩行距 離分布であることがわかる。

\section{5. 継続歩行距離の減少に必要な休㮩施設の量と整備方針}

Fig.6 と Fig.7は, 対象地区において, $r_{\text {grid }}=125$ と $r_{\text {grid }}=100$ とな る休喤施設密度のもとで, 休鄎施設を一様ランダムに分布させたも のである、Table1から，花壇等を休㮩施設として扱うことで，最近 隣距離が $100 \mathrm{~m}$ 以上となる確率 $\alpha$ は 0.28 から 0.14 一改善することがわ かる. 前述したように, 高齢者の約 $65 \%$ の設置希望間隔は $100 \mathrm{~m}$ 未満 であることを考虑すると, 確率 $\alpha$ をらに改善する必要がある. (15) 式において $\alpha=0.03, r_{\max }=100$ のと， $r_{\text {grid }}=75 \mathrm{~m}$ となる. Table 1 から， $r_{\text {grid }}=50$ と設定するとき, 確率 $\alpha$ は0に改善することがわかる. 休款施設を正方格子状に $100 \mathrm{~m}$ 間隔で均等配置する場合, ベンチの 設置地点の総数を現状の67（地上の場合）から109に増やす必要が 
ある.ところが, 最奇りの休㮩施設までの最近隣距離を $100 \mathrm{~m}$ 未満 $(\alpha=0)$ にするためには， $r_{\text {grid }}=50$ となる休秘施設の密度基準を満 たす必要がある. 対象地区の場合,この密度基準を満たすためには, ベンチの設置地点の総数を現状の67から436に増やす必要がある. 他方， $\alpha=0.03$ にするためには， $r_{\text {grid }}=75$ となる休息施設の密度基準 を満たす必要がある。この密度基準を満たすには, ベンチの設置地 点の総数を現状の67から194に増やせば十分である. Fig.8 8 Fig.9 は, 対象地区において, $r_{\text {grid }}=50$ と $r_{\text {grid }}=75$ となる休憩施設密度の もとで，休㮩施設を一様ランダムに分布させたものである．両者の

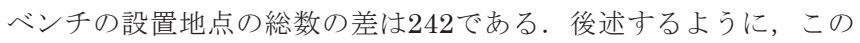
差を解消寸る方法は複数考えられる.

とくに，地下の公共空間におけるベンチは，丸の内地区と大手町 1丁目の一部に整備されているのみである（Fig.5の白丸十字および 白十字の地点). 今後, 地下の公共空間においても, 継続歩行距離の 減少に資するベンチの整備は重要である. Fig.6からFig.9までのよ うに, 一様ランダムな休息施設の分布は, ベンチの設置地点の総数 に応じて配置を検討する際の規範となるであろう。

前述したように，現実の都市空間において，休憩施設を等間隔に 整備するのは様々な理由により困難である，等間隔に設置できるな らば，休䡯施設の整備地点の総数は109で十分である.ところが, 対象地区の場合, 公共空間は複数の事業者によって管理されている ため, 対象地区全体で休息施設を等間隔に整備することは不可能で あろう。現実的には，事業者ごとにある程度の余裕をもって休咊施 設を整備するのが望ましいと思われる．Fig.8と Fig.9（休輴施設の 整備地点の総数はそれぞれ436と 194）は，個々の事業者による休款 施設の整備結果を対象地区全体で見渡したときの一つの分布として 捉えることもできる.

ベンチの設置地点の総数を増やす方法として, ベンチの整備に加 えて，1)花壇の縁のように座ることができる空間，2)階段の一部に おいて座ることのできるような空間, 3)立ち止まって休むことがで きるような空間の整備も有効であると考えられる. ベンチがない場 所であっても, 歩行者は座ることができる環境を必要に応じて発見 し作り上げている ${ }^{12), 13)}$. 対象地区では, 花壇等の設置地点は多数あ るため, 花壇の縁の幅を広くすることにより，休㲘施設を増加する ことはできると思われる，また，東京駅八重洲口では，階段に座る 高齢者も散見された。このような取り組みによって, 休息施設の増 加を図ることを提案したい，前述したように，東京駅八重洲口の心゙ ンチの総数は丸の内側と比較して少ない. とくに, 八重洲口では地 下街が面的に広がる反面, 地下の公共空間におけるベンチの設置は 皆無である. 継続歩行距離の減少を図るためにも, ベンチの設置に 加えて, 地上への連絡階段の一部を座ることのできるような空間と して整備することを提案したい. 近年, 階段等の段状構造がきっか けとなり, 歩行者が着座滞在している場面も報告されている13).

このように，ベンチ等の休憩施設の増加は継続歩行距離の減少を 図るために重要である反面, 事業者による維持管理の負担, ベンチ 等へのバンダリズム行為も懸念される．吉田(2014)が指摘するよう に, ベンチへのいたずらや污損, 破壞, 飲酒等の迷惑行為により, 事業者のベンチの固定設置に対する忌避感は大きいとも言われてい る14). また, 花壇等へのバンダリズム行為も懸念され, 花壇の縁に 着座できないようにする事例や, 設計段階において花壇の縁を傾斜

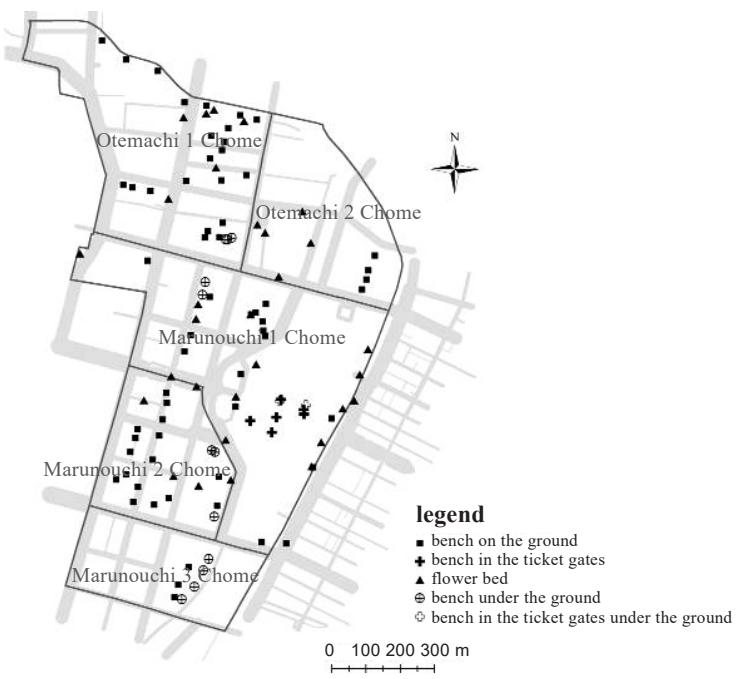

Fig.5 Location of resting places in Otemachi and Marunouchi

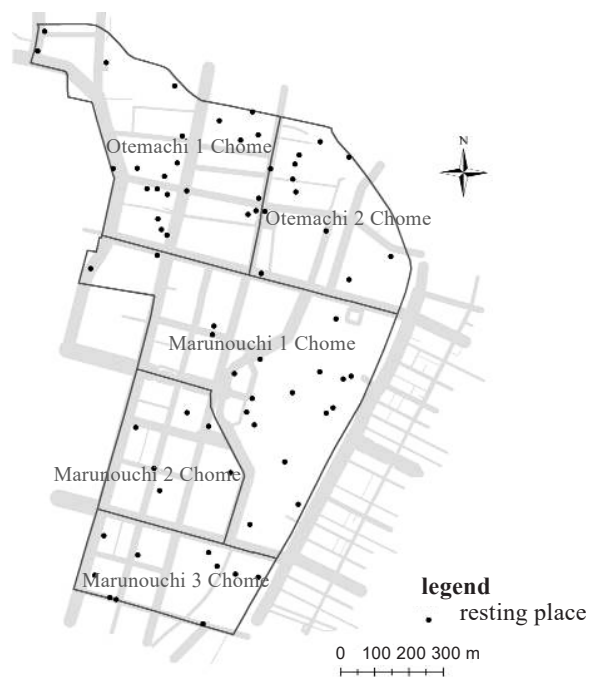

Fig.6 Random location of resting places $\left(r_{\text {grid }}=125 \mathrm{~m}\right)$

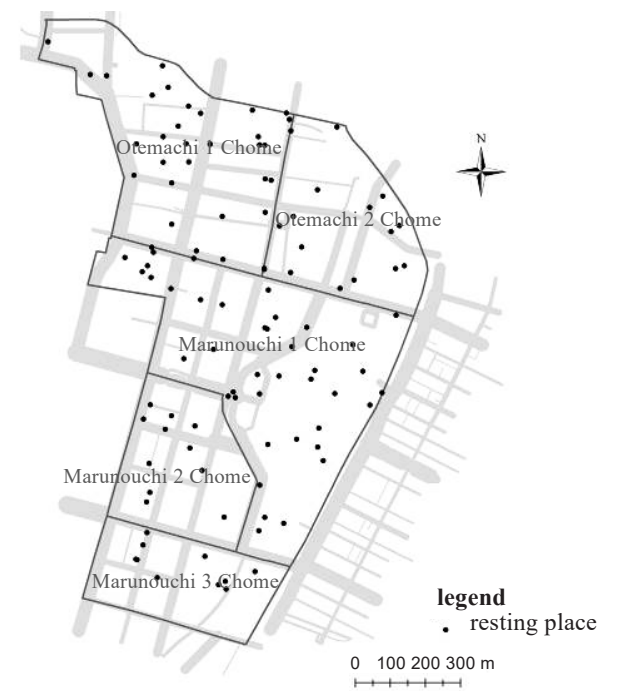

Fig.7 Random location of resting places $\left(r_{\text {grid }}=100 \mathrm{~m}\right)$ 


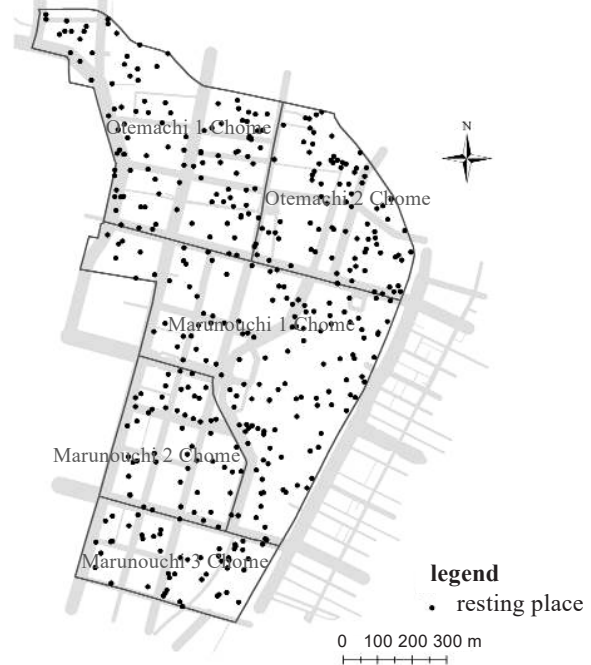

Fig.8 Random location of resting places $\left(r_{\text {grid }}=50 \mathrm{~m}\right)$

させている事例も存在する. ベンチの設置に対する事業者の忌避感 を軽減するためにも，ハード面では，上述の1)から3)までのような 方法をベンチ増設の代替案として提案するとともに, ソフト面では, ベンチや花壇等の休䅨施設の意匠の工夫をすることで, バンダリズ 厶行為を誘発しない上うな取組も重要であると考えられる。

\section{6. おわりに}

本稿では, 休頽施設の量（密度）と継続歩行距離の関係を, 平面 上における最近隣距離分布を規範として考察し, 東京駅および大手 町駅周辺を対象に, 現状の休数施設の密度で実現しうる継続歩行距 離分布を明らかにした。 また, 継続歩行距離分布を改善するために 更に必要な休㮩施設の総数を明らかにした。主な結論はつぎのとお りである。

第一に，対象地区におけるベンチの設置地点の総数は81（地上と 地下それぞれ67と14）であり，1)東京駅八重洲口のベンチの設置地 点の総数は丸の内側と比較して少ないこと，2)地下の公共空間にお けるベンチの総数は丸の内 $2 丁$ 目と大手町 $1 丁$ 目の一部のみである こと, 3)地上の公共空間の場合, 着座可能な花壇等を含めた休䈍施 設の総数は 97 であることがわかった.

第二に，永代通りと日比谷通りに沿って $x-y$ 平面座標系を設定し， 直交距離に基づいて現状の休鄎施設の密度で実現しうる継続歩行距 離分布を推定した結果，1)ベンチのみに着目寸ると，概ね $x_{\text {grid }}=125$ となる休想施設密度のもとで実現する継続歩行距離分布であること，

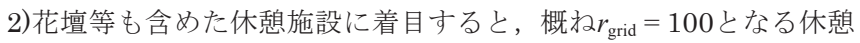
施設密度のもとで実現する継続歩行距離分布であることがわかった. ベンチのみに着目した場合, 最近隣距離が $100 \mathrm{~m}$ 以上となる確率 $\alpha$ は 0.28 である一方で, 着座可能な花壇等を休頽施設として扱うことで, 確率 $\alpha$ は 0.14 一改善することがわかった。

第三に, 確率 $\alpha$ をに方るためには, ベンチの設置地点の総数を現 状の67から436に増やす必要があることがわかった。他方, 確率 $\alpha$

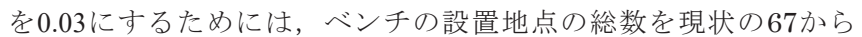

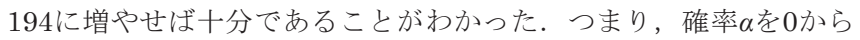
0.03 に僅かに許容するだけでも, ベンチの設置地点の総数は 242 も

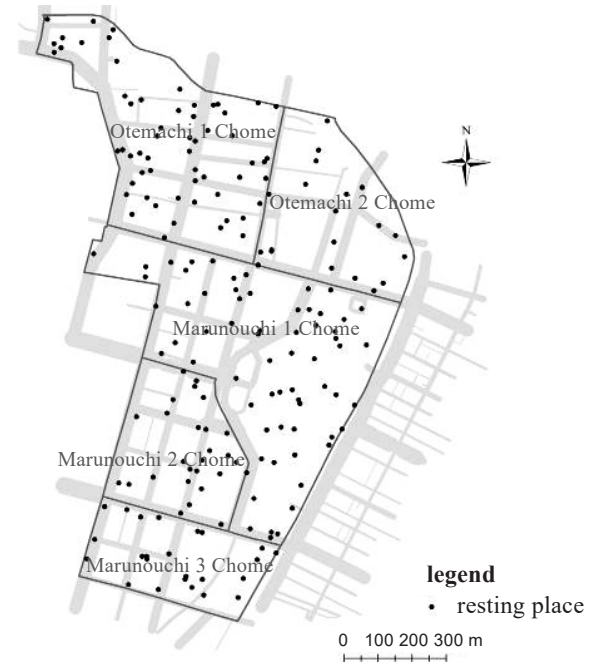

Fig.9 Random location of resting places $\left(r_{\text {grid }}=75 \mathrm{~m}\right)$

減少することがわかった.

確かに, 丸の内仲通りや行幸通りのように, エリアマネジメント 組織等によって休㲘施設の整備は増加傾向にある ${ }^{15)}$. その一方で, 対象地区全体で見渡すと, 高齢者が難なく継続歩行するためには, より多くの休㕰施設を整備する必要がある. とくに, 高齢者はより 安全かつ快適な歩行経路を選択寸る傾向にあることから, 日陰や卜 イレの配置やバリアフリー対策の有無によって, 歩行距離はより長 くなる傾向にある. このため, 継続歩行距離の減少を図るための施 策は重要であると考えられる. 政策目標として, 最近隣距離が $100 \mathrm{~m}$ 以上となる確率 $\alpha$ を段階的に減少し，ベンチの総数を徐々に増加す ることが現実的な整備方針であると考えられる．また，前節におい て提案したように， ベンチの整備に加えて，1)花壇の縁のように座 ることができる空間，2)階段の一部において座ることのできるよう な空間，3)立ち止まって休むことができるような空間の整備も有効 であると考えられる，花壇の縁の幅を着座可能な程度に広くするこ とにより，休䭒施設を増加することはできると思われる．とくに， 高齢者や障がい者などは，1)や2)のように着座可能な休㮩施設の使 用を優先し，それ以外の人々は3)のように立ち止まって休む施設の 使用を促すことで，前者の着座可能性を向上する工夫も重要である と考えられる.

上述の整備方法の利点と欠点を整理すると，花壇や階段は維持管 理されているため，着座や立ち止まって休む等の滞留可能な花壇や 階段として整備することは, ベンチそのものを増設するよりも, 事 業者の維持管理費用の負担軽減に寄与寸ると考えられる。他方, 花 壇や階段そのものを整備するよりも費用は高くなるおそれがある. また，着衣の污れを心配して着座が敬遠されること, ベンチに限ら ず花壇や階段等へのバンダリズムが行われることも懸念される。こ のように，整備方法の実現可能性の観点において，解決すべき課題 が残されている。 これらの課題の解決方法として, エリアマネジメ ント組織等による面的かつ一体的な休慜施設の整備（ハード面）と 維持管理（ソフト面）を行う方法は有効であると思われる. 個々の 事業者による整備費用負担の軽減と効率的な維持管理の観点からも, 面的かつ一体的な休息施設の整備と維持管理は重要であると考えら 
れる.

主な今後の課題はつぎの二点である. 第一に, 歩行空間のモデル 化の妥当性を検証する必要がある。本稿では, 平面上に休熄施設が 分布する状況を考えた. 他方, ネットワーク空間上に休䕀施設が分 布する状況を考えることもできる，ところが，現実の都市空間にお ける歩行経路の自由度は, ネットワーク空間上よりも高く, 平面上 よりも低いと考えられる. 歩行空間のモデル化の違いが継続歩行距 離分布に及ぼす影響については今後の課題としたい. 第二に, ベン チそのものの増設と花壇や階段等を滞留可能な休頽施設として整備 する際の実現可能性を検討する必要がある. 本稿では, 継続歩行距 離分布を改善するために更に必要な休慜施設の総数を明らかにし, 休㮩施設の設置地点を規範的に示した。一方で，1)具体的な設置場 所，2)ベンチや花壇等の意匠，3整備費用と維持管理費用の試算， 4)バンダリズム行為を防ぐための「使い方」と「維持管理」などの ソフト面の検討が残されている. とくに, 具体的な設置場所につい ては, 日陰の有無やトイレへの近接性も考慮することで, 高齢者の 歩行を促すための工夫をする必要があると考えられる.

\section{謝辞}

東京大学空間情報科学研究センターの中村和彦特任研究員から ArcGIS OnlineおよびCollector for ArcGISの操作法を教えて頂き ました。 また, 東京大学の浅見泰司教授, 日本OR学会2017年秋季 研究発表会の場において貴重なコメントを頂きました. さらに, 若 名の査読者より論文の内容を明確にするためのコメントを頂きまし た. 本研究はJSPS科研費JP17K12978の助成を受けたものです.こ こに記し謝意を表します。

注

注1）国土交通省，独立行政法人都市再生機構，三菱地所株式会社，三井不動 産株式会社のプレスリリース資料に基づき作成した。

注2）べンチおよび花壇等の位置情報は, 米国ESRI社のCollector for ArcGIS および東京大学空間情報科学研究センターが学内向けに提供する ArcGIS Onlineを使用して収集した。

\section{参考文献}

1) Ministry of Land, Infrastructure, Transport and Tourism: Guidelines for Town Planning in Terms of Health, Medical Care and Welfare, 2014.8 (https://www.mlit.go.jp/common/001049464.pdf) (in Japanese) (accessed 2017.9.1)

国土交通省都市局まちづくり推進課，都市計画課，街路交通施設課，「健 康・医療・福祉のまちづくりの推進ガイドライン (技術的助言) 」, 2014.8 (https://www.mlit.go.jp/common/001049464.pdf) (accessed 2017.9.1)

2) Etman, A., et al.: Characteristics of residential areas and transportational walking among frail and non-frail Dutch elderly: does the size of the area matter?, International Journal of Health Geographics, vol.13, no.1, 7, 2014.3

3) Doi, S., et al.: A study on the establishment of resting facilities for elderly, Proceedings of Infrastructure Planning, no.22, pp.925-928, 1999.10 (in Japanese)

土居聡, 三星昭宏, 北川博已, 高齢者を考慮した歩行空間の休䄽施設設 置に関する研究, 土木計画学研究・講演集, no.22, pp.925-928, 1999.10

4) Kitagawa, H., et al.: A study on the establishment of resting facilities for elderly, Infrastructure Planning review, vol.17, pp.981-987, 2000.9 北川博已, 土居聡, 三星昭宏, 歩行空間における高齢者のための休想施 設設置に関する研究, 土木計画学研究・論文集, vol.17, pp.981-987, 2000.9 (in Japanese)

5) Oshima, H., et al.: Travel behaviors and use of sitting spaces of the aged -A case of Shinagawa ward-, Journal of Architecture, Planning and Environmental Engineering (Transactions of AIJ), No.563, pp.171-177, 2003.1 (in Japanese)

大島秀明, 天野克也, 浅沼由紀, 谷口汎邦, 高齢者の外出行動と座りスペ 一ス利用に関する研究一品川区の場合一, 日本建築学会計画系論文集, No.563, pp.171-177, 2003.1

6) Kakinuma, M., et al.: A study on behavioral characteristics in stay of elderly visitor -A case study of Sugamo Jizo-dori shopping mall-, Journal of the City Planning Institute of Japan, vol.43, no.3, pp.625-630, 2008.10 (in Japanese)

柿沼美紀, 十代田朗, 津々見崇, 高齢来街者の滞留行動特性に関する研 究一单鴨地蔵通り商店街を対象として一, 都市計画論文集, vol.43, no.3, pp.625-630, 2008.10

7) Getis, A. and Boots, B.: Models of Spatial Processes An Approach to the Study of Point, Line and Area Patterns, Cambridge University press, 1978

8) Koshizuka, T:: On the relation between the density of urban facilities and the distance to the nearest facility from a point in a given area, Journal of the City Planning Institute of Japan, vol.20, pp.85-90, 1985 腰塚武志, 都市施設の密度と利用者からの距離との関係について, 都市 計画論文集, vol.20, pp.85-90, 1985 (in Japanese)

9) Clark, P. and Evans, F.: Distance to nearest neighbor as a measure of spatial relationships in population, Ecology, vol.35, pp.85-90, 1954

10) Suzuki, T. and Miura, H.: Spatial distributions of flow density and crossing density and the dependency on routing system, Journal of the City Planning Institute of Japan, vol.51, no.3, pp.909-914, 2016.10 (in Japanese)

鈴木勉, 三浦英俊, 都市内の移動経路と流動量密度・交差密度の空間分布, 都市計画論文集, vol.51, no.3, pp.909-914, 2016.10

11) Kurita, O.: Mathematical Models in Urban and Regional Studies -Methods in Urban Analysis-, Kyoritsu Shuppan Co., Ltd., 2013.9 (in Japanese)

栗田治, 都市と地域の数理モデル一都市解析における数学的方法一, 共 立出版, 2013.9

12) Sakaguchi, M., et al.: A Study an Openspace Structure and Sitting Stationary People - Station Square, and So on, Summaries of Technical Papers of Annual Meeting Architectural Institute of Japan Kyushu Branch (Architectural planning), no.45, 449-452, 2006.3 (in Japanese)

坂口真弓, 坂井猛, 有馬隆文, 屋外広場における着座滞留と空間構成に関 寸る研究：駅前広場等を対象として, 日本建築学会研究報告 九州支部, no.45, 449-452, 2006.3

13) Kondo, K., et al.: A study of sitting activities in urban open space with steps: Case study on the day with attraction, Summaries of Technical Papers of Annual Meeting Architectural Institute of Japan Kinki Branch (Architectural planning), no.47, 209-212, 2007.5 (in Japanese) 近藤幸介, 小西至一, 林田大作, 段状構造を持つ都市オープンスペースに おける着座滞在に関する研究: イベント開催日におけるケーススタディ, 日本建築学会近畿支部研究報告集, no.47, 209-212, 2007.5

14) Yoshida, T.: Shop manager's intention whether to set benches for elderly passersby to shopping streets in Kyoto city center, Journal of the City Planning Institute of Japan, vol.49, no.3, pp.795-800, 2014.10 (in Japanese)

吉田哲, 京都中心市街地商店街の個店における高齢の来街者向けベンチ の設置意向, 都市計画論文集, vol.49, no.3, pp.795-800, 2014.10

15) The Council for Area Development and Management of Otemachi, Marunouchi, and Yurakucho.: The Council for Area Development and Management of Otemachi, Marunouchi, and Yurakucho 2016, 2016,5 (URL:http://www.otemachi-marunouchi-yurakucho.jp/wp/wp-content/t hemes/daimaruyu/pdf/info_daimaruyu_2016.pdf) (in Japanese) (access ed 2017.9.1)

一般社団法人大手町・丸の内・有楽町地区まちづくり協議会, 大丸有協議 会パンフレット, 2016.5 (URL: http://www.otemachi-marunouchi-yu rakucho.jp/wp/wp-content/themes/daimaruyu/pdf/info_daimaruyu_20 16.pdf) (accessed 2017.9.1) 


\section{CONTINUOUS WALKING DISTANCE AND CRITERIA FOR DENSITY OF RESTING PLACES}

Application to Tokyo central station and Otemachi station

\section{Hiroyuki USUI ${ }^{* 1}$ and Kimihiro HINO ${ }^{2}$}

*1 Assist. Prof., Dept. of Urban Engineering, School of Engineering, The University of Tokyo, Dr.Eng.
${ }^{* 2}$ Assoc. Prof., Dept. of Urban Engineering, School of Engineering, The University of Tokyo, Dr.Eng.

According to the technical advice from the government of Japan, continuous walking distance tends to range from $500 \mathrm{~m}$ to $700 \mathrm{~m}$ and the distance tends to be shortened as people get older. In the literature, it was found that (1) 65\% of elderly persons are satisfied if the interval between resting places is shorter than $100 \mathrm{~m}$; and (2) 70\% of elderly persons are satisfied if its interval is shorter than $50 \mathrm{~m}$. In particular, when walking around Tokyo central station and Otemachi station, continuous walking distance is more than $100 \mathrm{~m}$. Although continuous walking distance tends to be longer than $100 \mathrm{~m}$, a sufficient number of resting places is not provided. To make urban space more walkable for elderly persons, continuous walking distance needs to be decreased by increasing the number of resting places. However, the relationship between the continuous walking distance distribution and the density of resting places has not been sufficiently theoretically investigated.

In this article, we investigated the aforementioned relationship with the application of the nearest neighbour distance distribution. Based on this theoretical model, we evaluated the number of resting places in order to improve continuous walking distribution. As the empirical study area, Tokyo central station and Otemachi station and their surroundings were selected. It was found that (1) the number of benches is 81 (67 (on the ground), 14 (under the ground)); (2) the number of resting places is 97 if flower beds are used as resting places; (3) the probability that the nearest distance between locations of benches is longer than $100 \mathrm{~m}$ is 0.28 ; (4) if flower beds are used as resting places, then its probability is 0.14 ; and (5) if its probability is to be close to 0 , the number of additional resting places would be increased to 194 which is approximately 3 times larger than the present number.

Based on these theoretical investigations, we proposed the following practical ways rather than increasing the number of benches per se. First, flower beds are improved such that their edges have the appropriate width to provide resting places. Second, stairs are improved to provide resting places. In particular, on the eastern side of Tokyo station at Yaesu gate, the number of resting places needs to be drastically increased. Improvement of stairs is a practical way because stairs are already used as resting places. Third, a practical way would be to provide resting places that are not for sitting. 